\title{
Türkiye'de Akıl Hastalığı Olan Hastalarda Zorla Yatırma ve Zorla Tedavi/
}

\section{Hukuki ve Etik Sorunlar *}

Involuntary Admissions And Treatment Of Patients With Mental Health Disorders-in Turkey / Legal And

Ethical Issues

\author{
Gürkan Serti, Hatice Özçelikii, Gülay Yıldırım iii
}

'Doç. Dr. Marmara Üniversitesi, Tıp Fakültesi, Tıp Tarihi ve Etik Anabilim Dalı https://orcid.org/0000-0002-0970-8406

iiMedipol Üniversitesi, Sosyal Bil. Enst. Sağlık Hukuku Doktora Programı https://orcid.org/0000-0002-8892-7630

iiiDoç. Dr. Sivas Cumhuriyet Üniversitesi, Tıp Fakültesi, Tıp Tarihi ve Etik Anabilim Dalı https://orcid.org/0000-0002-9589-7134

öz

Tıbbi girişimlerden önce kişilerin onamlarının alınması beden bütünlüklerine ve gelecekleri ile ilgili karar alma haklarına saygının gereğidir. Ancak bazı istisnai hallerde kişilerin onamı olmadan beden bütünlüklerine girişimlerde bulunulması hem etik açıdan hem de yasal açıdan kabul görebilmektedir. Hastalığı nedeniyle kendisine ya da başkasına zarar verme olasılığı olan akıl hastalarının zorla hastanelere, bakımevlerine, gündüz, gece, rehabilitasyon kliniklerine yerleştirilmesi ve tedavi edilmesi yasalarda düzenlenmektedir. Bu uygulamaların sınırları, gerekliliği, uygulanma şekli, ihlal ettiği haklar, sağladığı yararlar açısından hem tıp etiği hem de tıp hukukunda tartışmalıdır.

Türkiye'deki güncel uygulamada, kendine veya başkalarına zarar verme olasılığı bulunan akıl hastaları, genel ifadeler içeren, farklı kanun ve uluslararası sözleşmelerde yer alan maddelere göre kurumlara zorla yerleştirilmekte ve tedavi edilmektedir. Bu genel maddelerde, zorla yerleştirme kararının ne kadar süreceği, tedavinin uygulanmasının gerekip gerekmediği, zorla yerleştirilen kişinin hakları gibi konularda bilgiler bulunmamaktadır. Bu gibi belirsizliklerin neden olacağı olumsuzlukların giderilmesi için uygulama ile ilgili ek yasal düzenlemelere ihtiyaç vardır.

Makalemizde Türkiye'de akıl hastalığı nedeniyle bireylerin zorla yatırılması ve tedavi edilmesi ile ilgili hükümler, özerklik ve zarar vermeme ilkeleri ile tıp hukuku açısından incelenmiş ve Ruh Sağlığı Yasa Tasarısı ile karşılaştırıımıştır.

Anahtar Kelimeler: Gönülsüz tedavi, akıl hastaları, etik sorunlar

\section{ABSTRACT}

Having consents from patients before any kind of medical intervention is a necessity for the respect to patients' physical integrity and the right to their decision process about patients' future. However, in certain circumstances, it might have been accepted ethically and legally to make medical interventions without their consent. Involuntary admissions and treatments of patients with mental health disorders who present danger to themselves or to others have been regulated by laws. These practices are debated both in medical ethics and medical laws regarding to their boundaries, necessities, the way they are put into practices, the rights that they violate, the benefits that they provide.

In the current practice in Turkey, the patients with mental health disorders who present danger to themselves and to others are admitted and treated involuntarily according to articles in different laws and international conventions which includes general statements. In these general statements, there is no information about the duration about the involuntary admission decision, how long the admission will take place, whether the treatment is necessary, the rights of the patient who would be admitted involuntarily. In order to eliminate the negative outcomes of these kind of uncertainties, additional legal regulations are needed.

In our article, the provisions of involuntary admissions and treatment of patients with mental health disorders have been examined in terms of medical law along with the principles of autonomy and non-maleficence and compared with the draft of Mental Health Law in Turkey.

Key word: İnvoluntary admission, mental health disorders, ethic issues

*Lokman Hekim Dergisi, 2019; 9 (3): 393-404

DOI: 10.31020/mutftd.595300

Geliş Tarihi - Received: 22 Temmuz 2019; Kabul Tarihi - Accepted: 06 Eylül 2019

iletişim - Correspondence Author: Gürkan Sert < drgurkansert@gmail.com > 


\section{Giriş}

Akıl hastalarının tedaviye zorlanması, psikiyatride önemli etik ve yasal sorunların tartışıldığı bir başlıktır. ${ }^{1,2}$ Hastayı tedaviye zorlamanın, hastanın özerkliğini sınırlama, açııından getirdiği sonuçlar, sağlık çalışanlarının etik ve yasal sorunlar ile karşılaşmasına neden olmaktadır. ${ }^{3,4}$ Türkiye'de ve Dünya'da akıl hastalarının gönülsüz olarak tedavi edilmesi söz konusu olmaktadır. Örneğin Türkiye'de bir Ruh Sağlığı ve Hastalıkları Hastanesi'nde kliniğe yatırılan psikiyatri hastalarının \%13,1'inin istem dışı yatııılı̆̆ı belirlenmiştir. ${ }^{5}$ Dünya Sağlık Örgütü' nün İsviçre, Federal Almanya, Bulgaristan, Yugoslavya, Türkiye, Sudan, Hollanda'da yürüttüğü bir çalışmada, psikiyatri tedavisi görmekte olan hastaların \%5-20 oranında tedaviyi gönüllü olarak kabul etmemiş hastaların oluşturduğu belirtilmiştir. ${ }^{6}$

Hastaların zorla yatırılmasına karar verecek kişi, hastanelere, bakımevlerine, gündüz, gece rehabilitasyon kliniklerine, hastanın zorla yatırma nedenleri ve hastanın kalacağı süreler konusunda ülkelerde farklı düzenlemeler bulunmaktadır. Psikiyatri hastalarının tedaviye zorlanması için bazı ülkelerde kişinin kendisi veya diğer kişiler için taşıdığı tehlike göz önünde bulundurulurken, bazı ülkelerde de hastanın tedaviye ihtiyacının bulunup bulunmadığı göz önünde tutulmaktadır. ${ }^{2,3,7}$

Belirtmek gerekir ki akıl hastalığı ve zayıflığı bulunan kişilerin özgürlüklerinin sınılanması ve tedaviye zorlanması ile ilgili uygulama ve yasalarda insan hakları ve özgürlüklerine uygun yaklaşımların sağlanması, konunun tıp etiği çerçevesinde değerlendirilmesine bağıdır. Örneğin "Akıl Hastalığı Olan Kişilerin Korunması ve Akıl Sağlığı Hizmetinin Geliştirilmesi İçin Illkeler" de etik ilkelere uygunluk, aydınlatma ve kişisel özerklik temel alınmaktadır. ${ }^{8}$ Buna göre; her hastanın en az kısıtlayıcı ortamda ve en az zarar göreceği şekilde tedavi görme hakkı vardır. Akıl sağlığı hizmetlerinin, her zaman, akıl sağlığı uzmanlarının uygulanabilir etik standartlarına göre verilmesi gerektiği de vurgulanmıştır. Ayrıca "Birleşmiş Milletler Engellilerin Haklarına ìlişkin Sözleşme" nin de bu konuda önemli bir içerik taşıdığına işaret edilmektedir. ${ }^{7}$ Bu kapsamda bireylerin özerkliklerinin sınırlanması ve beden bütünlüklerine müdahale ile sonuçlanabilecek bu uygulamalarda bireylere en az zararı verecek ve özerkliklerini en az şekilde ihlal edecek yaklaşımların gösterilmesi esas alınmalıdır. Ülkemizde bu konuda ayrı düzenleme bulunmamakla birlikte bir yasa tasarısının ve etik kodun bulunduğunu belirtmek gerekir. ${ }^{9,10}$ Incinebilir grup içinde olan ruh sağlığı hastalarının haklarının korunması ayrıcalık ve özen gerektirmektedir. ${ }^{11}$

\section{Türk Hukukunda Durum}

Türkiye'de akıl hastalığı bulunan kişilerin zorla tedavisi konusunda önemli hükümler, insan Hakları Avrupa Sözleşmesi, Anayasa, Türk Medeni Kanunu ve Biyoetik Sözleşmesi'nde yer almaktadır. ${ }^{12}$

Insan Hakları Avrupa Sözleşmesi

Türkiye açısından bağlayıcı bir sözleşme olan İnsan Hakları Avrupa Sözleşmesi, herkesin özgürlük ve güvenlik hakkına sahip olduğunu belirtmektedir (madde 5). Aynı maddede yer verilen bazı hallerde kanunlara uygun olmak koşulu ile kişilerin özgürlüğünden yoksun bırakılabileceği belirtilmiştir. Bu kapsamda yer verilen istisnalar arasında, akıl hastalarının belli koşullarda özgürlüğünün sınırlanması da vardır (madde 5/e). Insan Hakları Avrupa Mahkemesi, akıl hastalarının zorla tedavisi ile ilgili kararlarında Insan Hakları Avrupa Sözleşmesi'nde yer alan işkence yasağı (madde 3) ile özgürlük ve güvenlik hakkı (madde 5) kapsamında karar vermektedir. İnsan Hakları Avrupa Mahkemesi, bu kararlarda, zorla tedavinin tıbben gerekli olması ve tedavinin insanlık dışı ve onur kırıcı olup olmaması konuları üzerinde önemle durmuştur. İnsan Hakları Avrupa Mahkemesi, kararlarında kişinin akli dengesinin yerinde olmaması gerekçesiyle özgürlüğünün kısıtlanabilmesinde, kişinin akli dengesinin yerinde olmadığını gösteren güvenilir uzman doktor raporu, akıl hastalığının zorunlu kapatmayı gerektirecek derecede olması, kısıtlılık halinin devamının hastalığın kalıcılığına bağlı olması şartlarını aramaktadır. ${ }^{7}$ 


\section{Biyoetik Sözleşmesi}

Biyoetik Sözleşmesi'ne göre, uygulanması düşünülen tedavinin gerçekleştirilmemesi halinde akıl hastalığı olan bireyin sağlığına önemli zararlar gelecekse, akıl hastalığı olan bireyin onamı olmadan, tedavisi için girişimler gerçekleştirilebilecektir. Maddede akıl hastalığı olan kişinin toplum için tehlike taşıma şartına yer verilmemiştir (madde 7).

\section{Anayasa}

Anayasa'da kimsenin özgürlüğünden yoksun bırakılamayacağı hükmüne yer verildiken sonra kişilerin özgürlüğünden yoksun bırakılacağı bazı durumlar da belirlenmiştir. Bunların arasında kişilerin tedaviye zorlanabileceği bazı durumlar da yer almaktadır. Buna göre; toplum için tehlike arz eden akıl hastaları, uyuşturucu madde veya alkol tutkunları, hastalık yayabilecek kişiler, kanunlarda öngörülen sınırlarda ilgili kurumlara zorla yatırılabilecek ve tedaviye zorlanabilecektir (madde 19).

İnsan Hakları Avrupa Sözleşmesi'nde, Biyoetik Sözleşmesi'nde ve Anayasa'da kişilerin özgürlüğünden yoksun bırakılmasının istisnalarına yer verilirken bunun kanunlar kapsamında yapılmasına özellikle işaret edilmiştir. Bu kapsamda tedavi amaçlı da olsa kişilerin zorla kurumlarda alıkonması, kurumlara zorla yerleştirilmesi, kişilerin özgürlüğünün sınırlanması, kişilere zorla tıbbi girişimler gerçekleştirilmesi, kişilerin beden bütünlüğünün dokunulmazlı̆ı hakkının sınırlanması anlamına geleceğinden bu konuların yasa ile düzenlenmesi zorunluluğu vardır. Kişi haklarının sınırlanması ile ilgili yasaların Anayasa'nın 13'üncü maddesi çerçevesinde ölçülülük ve yasallık ilkelerine uygun bir şekilde hazırlanması gerekir. ${ }^{13}$ Bu bağlamda kişilerin zorla kurumlarda alıkonarak veya kurumlara zorla yerleştirilerek tedavilerinin yapılması için kişinin haklarına üstün bir kamusal hak bulunmalıdır. Bunun yanında bu kamusal hakkın korunması ancak öngörülen kısıtlama ile sağlanabilmelidir. Bunlara ek olarak kanunun getirdiği kuralların varlığı hakkında vatandaşın bilgi sahibi olabilmesi için kanunun ulaşılabilir olması, uygulamada keyfiliğe karşı koruma sağlanması, yetkili makama verilen yetkinin genişliği ve icra etme şeklinin de tanımlanması gereklidir. ${ }^{14}$

\section{Türk Medeni Kanunu}

Kişilerin zorla kurumlarda alıkonulması ve kurumlara yatırılması ve tedavi edilmesi ile ilgili hükümler, Türk Medeni Kanunu'nun 432'inci maddesinde koruma amacıyla özgürlügün kısıtlanması başlığı altında yer almaktadır. Maddede kişinin bir kuruma yerleştirilmesi veya alıkonulması sınırlı sayıdaki sebeplere bağlandığından bu nedenler dışında herhangi bir gerekçe ileri sürülemez. ${ }^{15,16}$ Bunlar; toplum için tehlike oluşturan akıl hastalığı, akıl zayıflığı, alkol veya uyuşturucu madde bağımlılığı, ağır tehlike arz eden bulaşıcı hastalık veya serserilik halleridir.

Türk Medeni Kanunu'nda yeralan koruma amacıyla özgürlüğün kısıtlanmasının, vesayet kurumu içinde olmayan tedavi ve bakım unsurunu barındırması nedeniyle önemli olduğu ve dikkatli uygulanması halinde gerekli bir kurum olduğu söylenmektedir. ${ }^{17}$ Buradaki amaç; ruhsal veya ağır bedensel hastalıkları nedeniyle toplum için tehlike oluşturan kişilerin kişisel korumalarının başka şekilde sağlanamaması halinde tedavi, eğitim ve ıslahları için elverişli kuruma yerleştirilmeleri ve hem koruma altındaki kişinin hem de toplumun korunmasıdır. ${ }^{18}$

Koruma amacıyla özgürlüğün kısıtlanması ayrıca Türk Medeni Kanunu'nun Velayet, Vesayet ve Miras Hükümlerinin Uygulanmasına Dair Tüzük (Tüzük)'te düzenlenmiştir. ${ }^{19}$ Tüzüğe göre kişinin özgürlüğü kısıtlanırken çevresine verdiği külfet belirlemede, aile, yakınlar, komşular ve çevre dikkate alınacaktır. 


\section{Koruma Amacıyla Özgürlüğün Kısıtlanmasının Şartları}

Türk Medeni Kanunu'nda akıl hastalığı ve zayıflı̆̆ı nedeniyle koruma amacıyla özgürlüğün kısıtlanması talebi yapılması görevi, görevlerini yaparlarken bu sebeplerden birinin varlığını öğrenen kamu görevlilerine verilmiştir (madde 432). Yine ilgili kişinin vasisi, ailesi, ona bakmakla yükümlü olanlar ve benzeri kişiler, sulh hukuk mahkemesi veya ilgilinin yerleşim yeri mahkemesinden koruma amacıyla özgürlüğün kısıtlanması talebinde bulunabilir. Kısıtlama kararını yetkili mahkemeler verir. Bu çerçevede koruma amacıyla özgürlügün kısıtlanması talepleri, kişi kuruma yatırılmadan önce yapılabildiği gibi, kişi kuruma yatırldıktan sonra da yapılabilmektedir. Koruma amacıyla özgürlüğün kısıtlanması kararının alınmasında koşullar vardır. Kişinin Ergin Olması

Türk Medeni Kanunu'nda ilgili maddede ve gerekçesinde ergin kişiler hakkında koruma amacıyla özgürlüğün kısıtlanması kararı alınacağı belirtilmiştir. Maddeye göre, kişi kısıtlı olmasa dahi (kişiye hukuki işlem yapabilmesi için yasal temsilci atanmamış olması) maddede sayılan sebeplerden biri varsa kişi kuruma yerleştirilebilecek ve kurumda alıkonulabilecektir. Yargıtay da aynı yönde karar vermiştir. ${ }^{17-20}$ Türk Medeni Kanunu'na göre ergin kişiler, 18 yaşını dolduranlar, evli olanlar ve 15 yaşını dolduran ve mahkemece ergin kılınan kişilerdir (madde 11, 12).

\section{Akıl Hastalığı veya Akıl Zayıflığı/ Tıbben Tespiti}

Kişinin koruma amacıyla özgürlüğün kısıtlanması ve tedaviye zorlanması için Türk Medeni Kanunu kapsamında gereken koşullardan biri de kişide akıl hastalığı ya da akıl zayıflığı olmasıdır. Türk Medeni Kanunu'na göre, akıl zayıflı̆ı ve akıl hastalığııın varlığı, resmi sağlık raporu ile tespit edilmelidir (madde 436/5). Akıl hastalığı ya da akıl zayıflı̆ının varlı̆̆ı, kişinin koruma amacıyla özgürlüğün kısıtlanması kararının alınmasına yetmez. Bunların varlığı nedeniyle kişinin kendisi veya toplum için tehlike oluşturması da gerekir.

Türk Medeni Kanunu'nun 432'inci maddesinde akıl hastalığı ve zayıflı̆ı kavramlarının ne anlama geldiği ile ilgili herhangi bir tanımlama bulunmamaktadır. Türkiye Psikiyatri Derneği tarafından hazırlanan Ruh Sağlığı Yasası Taslă̆ı'nda ruhsal hastalık: "Temel ruhsal işlevlerde, bedende, toplumsal ilişkilerde ya da işlevsellikte aksamaya yol açan, psikoterapi, ilaç ya da diğer biyolojik tedaviler gibi tıbbi müdahale gerektiren geçici ya da kalıcı ruhsal yetersizlik ya da bozukluklardır." olarak tanımlanmıştır. ilgili maddede ruhsal hastalıkların, "yasalarda kullanılan akıl hastalığı, akıl zayıflığı, alkol, uyarıcı ve uyuşturucu madde kullanım bozuklukları (zararlı kullanım ya da bağımlıık) ile Dünya Sağıı Örgütü’nün hastalık sınıflandırmasında tanımlanan ruhsal bozuklukları" kapsadığı da belirtilmiştir (madde 3/j).

Akıl hastalığı ve zayıflığının tespiti için sağıı kurulu raporu istenecek ve kısıtlanacak kişi tam teşekküllü bir hastaneye sevk edilecektir. Mahkeme tarafından alınacak sağlık raporunda, hastanın medeni haklarını kullanıp kullanamayacaklarına dair soruların cevaplanması gerekir. Hasta, ayakta veya yatarak muayene edilir. Gözlem intisas Dairesinde yatan kişinin dosyasındaki tıbbi belgeler ve bulguları, muayene verileri hep birlikte değerlendirilir. Sonuçta sağlık raporu düzenlenir. ${ }^{21}$

Ruh Sağlığı Yasası Taslağı'nda ruhsal hastalıkların tanılanmasında ruhsal bozukluk ya da hastalık tanısı koymaya ruh sağlığı ve hastalıkları uzmanı hekimlerin, bu uzmanın bulunmadığı koşullarda diğer hekimlerin yetkili olması öngörülmektedir. Aynı maddede çocukların ruhsal gelişim bozuklukları ve ruhsal hastalık tanılarını koymaya çocuk ve ergen ruh sağlığı ve hastalıkları uzmanlarının yetkili olduğu, bunların bulunmadığı yerlerde erişkin ruh sağığı ve hastalıkları uzmanlarının bu görevi yerine getirebileceği belirtilmiştir (madde 12). 
Türk Medeni Kanunu'nda mahkeme tarafından hakkında rapor talep edilen kişinin ne kadar süre ile tanı için tutulacağı konusunda bir süre bulunmamaktadır. Mahkeme tarafından muayene ve sağlık kurulu raporu talep edilmeden önce de kendisi ya da toplum için tehlike arz eden kişinin bir kuruma yerleştirilmiş olması halinde de hastanın hangi sürede mahkemeye çıkarılacağı konusunda bilgiler bulunmamaktadır. Oysa Ruh Sağlığı Yasası Taslağı, bu konuda bazı sürelere yer vermektedir. Tasarı'ya göre acil nedenler ile zorla yatırılarak tedavisi yapılacak kişinin raporu, hakime hastane yönetimi tarafından 24 saat içinde ulaştıııı. Bu bildirimden itibaren 24 saat içinde ilk duruşma yapılır. İstemsiz yatıştan sonraki 48 saat içinde tedavisini sürdüren ruh sağlığı ve hastalığı uzmanının, hastalığa bağlı risk durumunun sürdüğü veya ortadan kalktığı ile ilgili raporunu hastane, en geç 24 saat içinde mahkemeye gönderir. Risk ortadan kalkmamışsa mahkeme kararına göre hareket edilir. Hasta, yatırılmaya itiraz eder veya hakim gerek görürse, bir ruh sağlığı ve hastalıkları uzmanından yeniden rapor alınarak yatış ya da tedavinin yerindeliği araştırıır. Bu durumda, bilirkişinin tıbbi muayenesini tamamlayarak raporunu 48 saat içinde mahkemeye sunması gerekir. Sulh Hukuk Hakimi, hastaneden gelen raporu ve atanmışsa bilirkişinin raporunu birlikte inceleyerek ve tarafları dinleyerek istemsiz yatışın ve tedavinin sürdürülmesine ya da sonlandırılmasına karar verir. Gerekli gördüğünde ek tıbbi açıklama isteyebilir ya da başka psikiyatri uzmanı görevlendirebilir.

Süreler konusunda önceden belirlemeye gidilerek, kişinin sağlık kurumunda kalacağı ya da kalmak zorunda olduğu sürenin belirlenmesi, hekim-hasta ilişkisi bağlamında hastanın özerkliğine saygı ve zarar vermeme ilkeleri açısından önemlidir. Sürenin belirlenmiş olması hastanın özgürlüğü açısından da güvence sağlayacağı gibi kötüye kullanımları da en aza indirecektir. Herhangi bir sürenin belirlenmemiş olması halinde de, hekimin olabilecek en kısa sürede gerekli tibbi işlemleri tamamlaması mesleki bir yükümlülüktür.

\section{Akıl Hastalığı ya da Zayıflığı Olan Kişinin Durumunun Kendisi ya da Toplum İçin Tehlike Oluşturması}

Koruma Amacıyla Özgürlüğün Kısıtlanması kararı için önemli bir husus da, akıl hastalığı ve zayıflığının toplum için tehlike oluşturup oluşturmadığının belirlenmesidir. Toplum için tehlike oluşmuş veya oluşacak ise mahkeme koruma amacıyla özgürlüğün kısıtlanması kararı verebilecektir. Hakim, resmi sağlık raporu aldırırken, raporda akıl hastalığı yada, zayıfığının toplum için tehlike oluşturup oluşturmadığı hususunun da yanıtlanmasını sağlamalıdır. ${ }^{16}$

Tehlike oluşturma ile ilgili görüş oluşturulmasında kültürel, geleneksel, ekonomik nedenlerle ülkelerin uygulama ve yasalarında farklııklar bulunmaktadır. Özgürlüğün sınırlanması için akıl hastalığının varlığı, bütün ülkelerde aranmakta iken, hastalığın ismi ve derecesi/şiddeti ülkelere göre değişebilmektedir. Bazı ülkeler, akıl hastalığı için daha spesifik psikotik hastalıkları ararken bazıları da akıl hastalığını geniş tanımlamaktadır. ${ }^{2}$

Türk Medeni Kanunu'nda kişinin toplum için ya da kendisi için tehlike oluşturması durumu ile igili herhangi bir açıklama bulunmamaktadır. Bu hususta açıklayıcı bilgilerin bulunması uygulamada keyfiliğin ve farklılıkların önüne geçecektir. Ruh Sağlığı Yasası Taslağı'nda kişinin acilen yatırıması ve tedavi edilmesi ile ilgili maddelerde özellikle kişinin zarar görebileceği durumlara ilişkin açıklayıcı bilgilere yer verilmiştir. Buna göre, ruhsal hastalığı ya da engeli olan kişiler, ayırt etme gücünün olmaması ya da hastalığının etkisiyle onam veremeyecek durumda olduğunda tedaviye zorlanabilecektir. Maddeye göre, kişinin durumu kendine ya da üçüncü kişilerin yaşamı veya beden bütünlüğüne yönelik ciddi bir tehlike oluştururyorsa, kişinin tedavi edilememesi sağlığı açısından yakın dönemde ciddi bir tehlike taşıyorsa veya kişinin durumu, müdahalede gecikilmesi kişinin organının ya da organının işlev kaybına neden olacaksa (acil tıbbi durumlarda) gerekli tedavi uygulanması için hastanın onayının alınması zorunlu değildir (madde 15/1). 


\section{Korumanın Başka Biçimde Sağlanamıyor Olması}

Türk Medeni Kanunu'na göre toplum için veya kendileri için tehlike oluşturan kişinin zorla yatışlarının yapılması için kişisel korunmasının zorunlu yatış ve tedavi dışında başka bir yolla sağlanamıyor olması gerekmektedir (madde 432). Özgürlüğü kısıtlanmaksızın da kişi korunabiliyorsa, koruma amacıyla özgürlüğün kısıtlanması kararı verilmemelidir. Yargıtay da aynı husususa dikkat çekmektedir. ${ }^{20-24}$ Örneğin kişiye vasi atanarak kişisel korunması sağlanabiliyorsa, bu tedbire karar verilmeyecektir. ${ }^{16}$ Korumanın hangi türde olması gerektiği ve hangi kapsamda sağlanacağı, somut olayın şartlarına ve hastanın ihtiyaçlarına bağlı olacaktır. $^{25}$

Verilecek sağlık raporuna dayanılarak hastann özgürlüğünün kısıtlanması mümkün olabileceğinden rapor hazırlanırken hastanın özerkligini en az etkileyecek yaklaşımlarda bulunulmalıdır. Koruma amacıyla özgürlüğün kısıtlanması kararı ile sonuçlanacak bir raporun verilmesi için hastanın özgürlüğünün sınırlanması dışında herhangi bir seçeneğin olup olmadığı incelenmelidir. Hastanın diğer bireyler veya kendine zarar verme olasılı̆ının önlenmesi ile ilgili en az sınırlayıcı kararların verilmesi öncelikle düşünülmelidir. Bu kapsamda, hastanın daha az sınırlanması ve beden bütünlüğüne daha az müdahaleyi gerektiren girişimlerin uygulanması için zarar vermeme ve özerklik ilkeleri bağlamında değerlendirmeler yapılmalıdır. Hekimin raporu hazırlaması sırasında yapılacak değerlendirme daha çok hastanın sağlık durumu çerçevesinde olabilecektir. Yargının da konuyu değerlendirme konusunda gerekli hassasiyeti göstermesi önemlidir.

\section{Kısıtlamanın Kişinin Tedavisi, Eğitimi ve Islahı Amacıyla Yapılması}

Kişinin özgürlüğü kısıtlanırken amaç, tedavisi, eğitimi veya ıslahıdır. Bu amaçlarla elverişli bir kuruma yerleştirilir veya alıkonulabilir. Ancak bahsedilen elverişli kurumun ne olduğu ve kısıtlamanın en az veya en çok ne kadar süre ile olabileceği veya tedavi sürecine dair nasıl vesayet makamının kontrolünün sağlanacağına dair düzenleme kanunda yer almamıştır. Kurumun elverişli olmasından anlaşılması gerekenin, organizasyonu ve personel yapısı itibariyle kişinin durumunun gerektirdiği temel ihtiyaçları karşılamak açısından yeterlilik olduğu savunulmaktadır. Kurumun elverişli olup olmadığı, özgürlüğü kısıtlanacak kişinin durumuna göre değerlendirilmelidir. Örneğin akıl hastalığı veya akıl zayıflığı nedeniyle özgürlüğü kısıtlanacak bir kişinin akıl hastanesi yerine huzurevine yerleştirilmesi halinde kurum elverişsizdir. ${ }^{18}$

Elverişli kurum kavramına yeme, içme, vücut bakımı, giysi gibi temel ihtiyaçların karşılanması ile asgari ölçüde kişisel bir uğraşın sağlanmasının da dahil edilmesi gerrektiği ileri sürülmektedir. Bu kapsamda kişinin hareket özgürlüğünün kurumdaki bakım ve gözetim sebebiyle hissedilir derecede sınırlanması halinde Türk Medeni Kanunu'nun 432'inci maddesi anlamında bir kurum söz konusu olduğu belirtilmektedir. ${ }^{(25)}$ Kurum kavramına hastaneler, gündüz ve gece klinikleri, rehabilitasyon klinikleri ve bakımevleri dahildir. ${ }^{(17)} \mathrm{Bu}$ düzenlemeler olmasa da sağılı kurumlarının hastaların zarar görmesinden dolayı sorumlu tutulmaları mümkündür. Yargıtay Hukuk Genel Kurulu kararında kendisine zarar verecek hastanın, intihar etmesinden dolayı hastaneyi sorumlu tutmuştur. Kararda kendisine zarar verme olasılığı olan hastanın durumuna uygun odalar tahsis edilmesinin yanında hastanın zarar görmesini engelleyecek nitelikte olması gerektiği belirtilmiştir. Bu bağlamda, odalarda özellikle elektrik anahtarı ve prizinin bulunması da yasaklanmış olmasına rağmen, davalı hastane işleteninin, olay yerinde bulundurmaması gereken televizyon anten kablosunun hasta tarafından ele geçirilmesine engel olamamasını emredici hukuk kurallarına da aykırı davranış olarak nitelemiştir. Aynı kararda hastane işleteninin Hasta Hakları Yönetmeliği'nin 37'inci maddesinde öngörülen hastanın can güvenliğini sağlama görevini yerine getirmediği de belirtilmiştir. 
Bu çerçevede Yargıtay Hukuk Genel Kurulu, hastanın intiharını engellemek için yeterli tedbirleri alamayan hastanenin sorumlu olduğuna karar vermiştir. ${ }^{26}$

Ruh Sağlığı Yasası Taslağı'nda da "elverişli kurum" tanımlanmamıştır. İstemsiz yatışın düzenlendiği maddeye göre, son çare olarak hakim kararı ile kişi uygun bir kuruma yerleştirilecektir (m. 15/3). Ancak aynı maddede yatışı ruh sağlığı hastanelerindeki tecrit, tespit ve gözetim uygulamalarının Türkiye'nin taraf olduğu Uluslararası Koruma Standartlarına uygun yürütüleceği de belirtilmiştir (m. 15/10).

Ruh Sağlığı Yasası Taslağı'nın "Ruh sağlığı sorunu olanların hizmet alma hakkı” başlıklı maddesine göre, en az kısıtlayıcı ortamda, gönüllü bir temelde, mümkün olduğunca kapsamlı, kişinin iyileşmesini, toplumla bütünleşmesini ve ekonomik kendine yeterliğini tesis edecek ruh sağlığı hizmetleri ve destekleri alma hakkı esastır (madde 7/d). Aynı maddeye göre, uluslararası ilkelere uygun toplum temelli iyileşme ve diğer ruhsal tedavi, rehabilitasyon ve bakım hizmetlerine ulaşma ve bu hizmetleri yaşadıkları kendi intiyaçlarına en uygun ortamda alma hakkı da vardır (madde 7/e). Ek olarak, hizmet alan kısıtlı bir ortamda zorunlu yatış ile kurumda kaldığı süre içinde tıbbi durumu elverdiği sürece, dış dünyayla iletişim kurma, ihtiyaç hissettiği oranda ziyaretçi kabul etme hakkına sahiptir (madde $7 / \mathrm{k}$ ). Bu anlamda kamu kurum ve kuruluşları, yerel yönetimlerin ya da özel kuruluşların hizmet ya da olanak düzenlemeleriyle ilgili uygulamalar, ruhsal sorunları ya da engeli bulunan kişilerin genel sağlığa ulaşım, barınma, eğitim, iş, sosyal güvenlik başta olmak üzere hiç bir hakkından eksik yararlanmaya yol açacak biçimde düzenlenemeyecektir (madde 7/2). Ruh Sağlğı Yasası Taslağı, ayrıca hastanede kalmasına gerek olmayan ancak sosyal destekten yoksun, kendi bakımını yapamayacak, bedensel ve ruhsal sağlığını korumayacak hastaların, sosyal çalışmacının raporu doğrultusunda hizmet alabileceği elverişli kurumlara yerleştirileceği öngörülmüştür (madde 16/k).

Yürürlükte olan mevzut incelendiğinde, Tüzüğün 57. maddesi (b) uyarınca, koruma amacıyla özgürlüğü kısıtlanan ergin kişinin tedavisi, eğitimi veya ıslahı için elverişli bir kuruma yerleştirilmesi veya alıkonulmasına ilişkin esas ve usulleri düzenleyen yönetmelik, Başbakanlığın koordinatörlüğünde Sosyal Hizmetler ve Çocuk Esirgeme Kurumu Genel Müdürlüğünün bağlı bulunduğu Bakanlık ile Adalet, İçişleri, Milli Eğitim ve Sağlık Bakanlıklarınca birlikte en geç bir yıl içerisinde çıkarılır. Ancak bahsedilen bu yönetmelik 2003 yılından bugüne halen çıkartılmamıştır.

\section{Mahkeme Kararının Varlığı}

Kısıtlama kararını yetkili mahkemeler verir. Kişinin ilgili sağlık kuruluşuna sevki, kuruma yerleştirme, alıkoyma ve kurumdan çıkartma kararı mahkeme kararına dayanmalıdır. Türk Medeni Kanunu'nun 437'inci maddesine göre, gerektiğinde ilgili kişiye adli yardım sağlanmalı ve karar verilirken mutlaka ilgili kişi dinlenmelidir. Adli yardımın amacı kişinin hak arama özgürlüğü önündeki engellerin kaldırıması ve eşitliğin sağlanmasıdır. Kanunun açık hükmüne göre mahkeme re'sen adli yardım sağlamalıdır. ${ }^{18}$

Temel hak ve özgürlüğün sınırlanarak zorla tedaviye izin verilen yargılamada, mahkemece karar verilmeden önce her türlü delil toplanmalıdır. Taraflarca gösterilen tanıklar da dinlenilmelidir. ${ }^{15,16}$ Mahkeme vesayete tüm delilleri re'sen de toplamalıdır. Yargıtay kişi ile ilgili Koruma Amacıyla Özgürlüğün Kısıtlanması kararının talep edildiği dosyada delil listesindeki tanıkların dinlenmemesine ve neden dinlenmediğinin gerekçelerine dayanarak kararı bozmuştur. ${ }^{27}$

Yargı kararlarına göre, özgürlüğü kısıtlanacak kişi hakkında verilen sağılk heyet raporlarında çelişkiler varsa bu çelişkiler mutlaka giderilmelidir. Uygulamada raporlar arasındaki çelişki Mahkemece Adli Tıp Kurmu'nun ilgili ihtisas dairesine hastanın sevki ve yeniden rapor alınması ile giderilmektedir. Koruma maksatlı vesayet altına alınma kararı için, hem sıhhi, hem de hadise ve delil araştırmasının mahkeme tarafından yapılması gerekmektedir. Uygulamada mahkemeler kolluk vasıtası ile ilgili ergin hakkında gereken araştırmayı yaptırmaktadır. ${ }^{27-29}$ 


\section{Karara İtiraz}

Türk Medeni Kanunu'nda, koruma amacıyla özgürlüğü kısıtlanan kişi ve yakınlarına kısıtlama ve kurumdan çıkarılma isteminin reddi kararına karşı itiraz hakkı tanınmıştır. Mahkeme tarafından özgürlüğünün sınırlanması ve tedavi kararının verilmesinden sonra kuruma yerleştirilen kişi veya yakınları, verilen karara karşı kendilerine bildirilmesinden başlayarak on gün içinde denetim makamına itiraz edebilirler (madde 435). Bu hak, kurumdan çıkarılma isteminin reddi hâlinde de kullanılabilir. Türk Medeni Kanunu'na göre, kararın sebebi hakkında ilgili kişinin mutlaka bilgilendirilmesi ve denetim makamına itiraz edebileceğine yazılı dikkatinin çekilmesi zorunludur. Mahkeme kararını gerektiren her işlem gecikme olmadan hakime ulaştırılır. "Yerleştirme kararı veren vesayet makamı veya hâkim durumun özelliklerine göre bu istemin görüşülmesini erteleyebilir" (madde 436/4).

Yakınları kavramının geniş olarak yorumlanarak örneğin ana, baba, çocuklar gibi hısımlık bağı dışında, vasi, doktor, öğretmen veya psikoloğun da bu kapsamda değerlendirilmesi gerektiği bildirilmektedir. ${ }^{(17)}$ Sulh hukuk mahkemesinin kararına karşı kanun yolları açık olup, denetim makamı olan Asliye Hukuk Mahkemesi'nin kararı kişi özgürlüğünün kısıtlanması gibi bir konuda vereceği kararlar kesin olup ve temyiz yolu kapalıdır.

Türk Medeni Kanunu'nda öngörülen özgürlüğü kısıtlayıcı tedbirler geçici önlemlerdir. Bu bağlamda kısıtlanan kişinin durumu uygun hale geldiği anda yerleştirildiği veya alıkonulduğu kurumdan çıkarılacaktır. Bir kuruma yerleştirilen veya kurumda alıkonan kişi, kurumdan çıkmak istediğini yetkili makama iletir ve istemi uygun bulunursa da kurumdan çıkarılır (made 432/3). Özgürlüğü kısıtlanan kişinin durumunun kurumdan ayrılmaya elvermesi halinde, kurum yöneticileri de, vesayet makamına başvurarak, kısıtlamanın kaldırılmasını talep edebilirler. Akıl hastalığı veya akıl zayıflığı sebebiyle kısıtlanan kişinin üzerindeki kısıtlama kararı Türk Medeni Kanunu'nun 474'üncü maddesine göre resmî sağlık kurulu raporu ile kaldırılmaktadır.

Anayasa'nın 19. maddesine göre her ne sebeple olursa olsun, hürriyeti kısıtlanan kişi, kısa sürede durumu hakkında karar verilmesini ve bu kısıtlamanın kanuna aykırılı̆ı halinde hemen serbest bırakılmasını sağlamak amacıyla yetkili bir yargı merciine başvurma hakkına sahiptir.

\section{KiŞiYi BíLGILENDIRME VE ONAM}

Türk Medeni Kanunu'nun 432'inci maddedesinin zorla tedavi için hukuki bir temel oluşturup oluşturmadığı koruma amacıyla özgürlüğün kısıtlanmasında önemli bir tartışma konusudur. Türk Medeni Kanunu'nun 432'inci maddesi kapsamında alınan koruma amacıyla özgürlüğün kısıtlanması kararının zorla tedavi için yeterli olmadığı zorla tedavinin yine yasa ile düzenlenmesi gerektiği savunulmaktadır. ${ }^{25}$

Hakkında koruma amacıyla özgürlüğün kısıtlanması kararı verilen kişinin bu karar hakkında bilgilendirilmesi gerektiği Türk Medeni Kanunu'nda belirtilmiştir. Ancak burada bilgilendirme mahkeme tarafından yapılmaktadır. Bu bağlamda buradaki bilgilendirme, tedaviyi yapacak hekim tarafından bizzat hastaya değil mahkeme tarafından özgürlüğü kısıtlanacak olan kişiye yapılmaktadır. Bu anlamda hekim-hasta arasında olması gereken bilgilendirmeden söz etmek mümkün olmayacaktır. Özellikle söz konusu akıl hastalığı ve rahatsızıı̆ına sahip iken, hastanın bilgilendirilerek aydınlatılmış rızasının alınmasından bahsedilemeyecektir.

Aslında bu yönde özel bir düzenleme olmasa da hastanın hakları çerçevesinde yatırıldığı kurumda bilgilendirmenin yapılması ve bundan sonra onamının alınması hastanın kendisinin onam veremeyecek durumda olması halinde yasal temsilcisinden onam alınması zorunludur. Her ne kadar mahkeme kararı hastanın tedaviye izin iradesi yerine geçse ve özgürlüğün kısıtlanmasının kanuni şartı olsa da, akıl hastalığı olan kişinin tedavi hakkında Hasta Hakları Yönetmeliği kapsamında bilgilendirilmelidir (madde 18/1 ve 
18/6). Yargılamaların aleni olduğu dikkate alındığında hastanın özel hayatının gizliliğinin korunduğunu söylemek pek de mümkün olamamaktadır. Bu anlamda uygulamada bu bilgilendirmenin kim tarafından hastaya yapıldığı, bunun ortamı mutlaka önem arzedecektir. Hastaya bilgilendirmenin kendisinden sorumlu olan hekim tarafından yapılması hastanin özerkliği ve zarar görmemesi açısından daha olumlu sonuçlar getirecektir.

Ruh Sağlığı Yasası Taslağı'na göre, istemsiz olarak kuruma yerleştirilecek kişiye tedavi uygulayan hekim, hastaya ve gerektiğinde yasal temsilcisine öngörülen tıbbi tedavinin sebebi, amacı, türü, yöntemi, riskleri, yan etkileri, tedavinin yapılmamasının olası sonuçları ve alternatif tedavi imkanları hakkında bilgi vermeli ve hastanın ya da yasal temsilcisinin onayına sunmalıdır. Tasarıya göre kişi ayırt etme gücünü yitirmeden önce tıbbi müdahale ile ilgili beyanda bulunmamışsa, tedaviyi uygulayacak hekim, hastayı temsil yetkisine sahip kişiyi bilgilendirecektir. Maddenin devamında ise ayırt etme gücü bulunmayan kişinin mümkün olduğu ölçüde karar verme sürecine katılmasının sağlanması, istemsiz tedavi ve istemsiz yatışın her aşamasında hizmet alan kişinin seçtiği savunucunun (advocate) sürece dahil edilmesi gerektiği belirtilmiştir. Ek olarak tedaviyi uygulayan kurumca tedavi planında öngörülen tıbbi tedbirlerinin yazılı olması ve buna karşı itiraz yollarının hastaya ya da savunucusuna bildirilmesi düzenlenmiştir (m. 15).

\section{Hastanın Kalacağı Süreler Ille iligili Belirsizlik}

Zorla yatırma ve tedavi süreleri konusunda ülkeden ülkeye farklılıklar söz konusudur. Amerika'da 1 yıldan başlayıp daha uzun sürebilmekte iken İsrail'de bu süre 6 aydır. Hastanın psikiyatrik değerlendirmesinin yapılıp yasal olarak zorla tedaviye başlama bakımından ülkeler arasında süre açısından farklılıklar bulunmaktadır. Bu süreler en az 24 saat en fazla 15 gün olmak üzere değişmektedir. İtalya'da hastanın zorla tedavi süresi 7 gün iken Belçika'da bu süre 2 yıl, Danimarka, Fransa, Portekiz ve İspanya'da ise böyle bir süre yoktur. Mahkeme veya diğer yetkililer bu süreyi 7 günden 12 aya kadar uzatabilmektedir. ${ }^{6}$

Türk Medeni Kanunu kapsamında mahkeme tarafından özgürlüğünün sınırlanması ve tedavi kararının verilmesinden sonra da hastanın kurumda kalacağı süreler veya kaldığı sürelerde denetleme ile ilgili bilgi bulunmamaktadır. Bu da hekimlerin sorumluluğunu arttırmaktadır. ${ }^{7}$

Ruh Sağlığı Yasası Taslağı'na göre bir mahkeme kararıyla verilebilecek en uzun istemsiz yatış ve tedavi süresi üç haftadır. Ancak risk içeren durum ortadan kalkmamışsa, ikinci haftanın sonunda hastane hastanın son durumunu rapor eder. İtiraz üzerine veya hakim tarafından gerekli görülürse bir ruh sağlığı ve hastalıkları uzmanı bilirkişi atanarak istemsiz yatış ya da tedavinin uzatılması yönünde tıbbi görüş alınır. Bilirkişi, tıbbi muayenesini tamamlayarak raporunu 48 saat içinde mahkemeye sunmalıdır. İstemsiz yatış ve tedavi süresinin uzatılmasının ya da kaldırılmasının önerildiği tedavi raporu üç aya dek tedaviyi sürdüren ruh sağlığı ve hastalıkları uzmanınca, sosyal inceleme raporu ise sosyal çalışmacı tarafınca düzenlenir. Üç aydan sonra ise hastane sağlık kurulunca düzenlenir.

\section{Sonuç}

Türkiye'de akıl hastalarının hastanelere, bakımevlerine, gündüz, gece, rehabilitasyon kliniklerine zorla yerleştirilmesi ilgili hüküm taşıyan düzenlemeler bulunmaktadır. Sözleşmelerin, Anayasa'nın ve Türk Medeni Kanunu'nun ilgili maddeleri genel hükümler içermektedir. Bu bağlamda kişinin özgürlügünün sınırlanması ve zorla tedavi edilmesi gibi kişi hak ve özgürlükleri ile ilgili önemli sınırlamalar getirebilecek bir uygulama konusunda yeterli ve açıklayıcı hükümlerin bulunmaması hem hukuki açıdan hem de tıp etiği açısından önemli tartışmalara neden olmaktadır. Ayrıca kişinin kuruma yatırılmasından önce ve sonrasında kişinin hasta olarak haklarını kullanabilmesi ile ilgili hükümler bulunmamaktadır. Bu kapsamda kişilerin özgürlüğünün sınırlanması ile ilgili sorunlar şu şekilde sıralanabilir: 
1. Düzenlemelerde tehlikelilik ile ilgili herhangi açıklayıcı bir ifade bulunmamaktadır. Tehlike oluşturma kavramının sınırlarının belirlenmesi güçlükler içerebilir. Bunların neler olabileceği sınırları kapsamı konusu tamamen uygulamaya kalmıştır. Bu durum birbirinden farklı uygulamalara neden olabilecektir. Bu kapsamda koruma özgürlüğü sınırlanacak kişinin topluma ve kendine zarar verme tehlikesinin bulunup bulunmadığı konusunda belirleme yapılırken ortak bazı kriterlerden hareket edilmesi için konu ile ilgili belirlemeler yapılmalıdır. Örneğin Ruh Sağlığı Yasası Taslağı'nda kişinin kendine zarar verme tehlikesinden ne anlaşılması gerektiği konusunda belirlemeler bulunmaktadır. Benzer yönde belirlemelerin yapılması raporları verecek hekimlerin uygulamalarında tereddütleri azaltacaktır.

2. Kişinin koruma amaçıı özgürlüğünün sınırlanması ile ilgili verilen raporlarda ve mahkeme kararlarında özgürlüğün sınırlanmasına son çare olarak başvurulması gerektiği her zaman göz önünde bulundurulmalıdır. Bu yönde gösterilecek yaklaşım da tıp etiği açısından yine özerklik ve zarar vermeme ilkeleri bağlamında önemlidir. Bu bağlamda hastanın daha az sınırlanması ve beden bütünlüğüne daha az müdahaleyi gerektiren girişimlerin uygulanması için zarar vermeme ve özerklik ilkeleri bağlamında değerlendirmeler yapılmalıdır. Ayrıca bu yönde bir değerlendirme olmadan alınan karar bireyin özerkliğinin sınırlanmasına neden olacaktır. Fakat hekimin raporu hazırlaması sırasında yapılacak değerlendirme daha çok hastanın sağlık durumu çerçevesinde olabilecektir. Yargının da konuyu değerlendirme konusunda gerekli hassasiyeti göstermesi önemlidir.

3. Kişinin tıbbi olarak akıl hastalığı veya zayıflığı yönünden değerlendirilmesinde süreler konusunda önemli yasal boşluklar vardır. Türk Medeni Kanunu'nda kişinin koruma amacıyla özgürlüğün kısıtlanması ile ilgili mahkeme kararı verilmeden önce topluma ya da kendine zarar verme tehlikesi nedeniyle alıkonulması ya da hastaneye yatırılması halinde ilgili raporun ne sürede hazırlanıp mahkemeye sunulacağı konusunda herhangi bir süre belirlenmemiştir. Aynı şekilde koruma amacıyla özgürlüğün kısıtlanması ile ilgili raporun hazırlanması konusundaki mahkeme taleplerinde de raporun ne kadar sürede hazırlanacağı ve mahkeme kararından sonra kişsinin ne kadar süre ile yatırılacağı ve tedavi altında tutulacağı konularında Türk Medeni Kanunu herhangi bir süre sınırına yer vermemiştir. Bu da hekimlerin sorumluluğunu arttırmaktadır. Ruh Sağlı̆̆ı Yasası Taslağı'nda olduğu gibi bu konu ile ilgili süreler konusunda önceden belirlemeye gidilerek kişinin sağlık kurumunda kalacağı ya da kalmak zorunda olduğu sürenin belirlenmesi hekim-hasta ilişkisi bağlamında hastanın özerkliğine saygı ve zarar vermeme ilkeleri açısından önemlidir. Sürenin belirlenmiş olması hastanın özgürlüğü açısından da güvence sağlayacağı gibi kötüye kullanımları da en aza indirecektir.

4. Kişilerin yerleştirileceği elverişli kurumun nitelikleri hakkında düzenlemelerde herhangi bir bilgi yer almamaktadır. Kişinin özgürlüğünün sınırlanması nedenleri ile bağdaşmayacak bir yere yatırılması kişinin hakkı ile bağdaşmadığı gibi tıp etiğinin zarar vermeme ve özerklik ilkeleri ile de bağdaşmaz. Kişinin hastalığı nedeni ile özgürlüğünün sınırlanması halinde ona zarar vermeyecek, yarar sağlayacak bir yerde bulundurulmalıdır. Bu çerçevede elverişli kurum ile ilgili belirlemelerin yapılması kişilerin yatırıma amaçlarına uygun yerlerde bakım almasını sağlayacaktır.

5. Hakkında koruma amacıyla özgürlüğün kısıtlanması kararı verilen kişinin aynı zamanda tedaviye zorlanıp zorlanmayacağı hususu tartışmalıdır. Özgürlüğün sınırlanması kararının kişinin tedavisi, ıslahı ya da eğitimi için yapılacağı Türk Medeni Kanunu'nda belirtildiğinden topluma veya kendine zarar verme olasılığı olan kişinin koruma amacıyla özgürlüğün kısıtlanması kararı verilmesi halinde zorla tedavi edilebileceği düşünülebilir. Ancak bu durum kişi hak ve özgürlükleri ile bağdaşmaz. Kişinin tedaviye zorlanması konusunda ayrıca karar verilmesi gerekir. Koruma amacıyla özgürlüğün kısıtlanması kararı verilmesinden sonra kişiye tedavi verilmesi planlanıyorsa, hasta, tedavi hakkında, tedaviden beklenen yarar, tedavinin verebileceği zarar, uygulanmaması halinde oluşabilecek sonuçlar ve varsa başka tedavi seçenekleri hakkında bilgilendirildikten sonra hastanın onamı alınmalıdır. Hasta karar verme yeterliliğine sahip değilse yasal 
temsilcisi bilgilendirildikten sonra yasal temsilcisinin onamı alınmalıdır. Ayrıca hastanın tedavi başladıktan sonra tedavinin durdurulmasını talep hakkına sahip olduğu da göz önünde bulundurulmalıdır. Hakkında koruma amacıyla özgürlüğün kısıtlanması kararının hastanın zorla tedavisi için dayanak alınması ve kişinin tedaviyi reddetme ya da durdurma hakkının göz önünde bulundurulmaması özerkliğe saygı ilkesine aykırıdır.

6. Hasta hakkında koruma amacıyla özgürlüğün kısıtlanması kararının verilmesinden sonra sahip olduğu haklar konusunda da bir düzenlemeye gidilmesi önemlidir. Örneğin hastanın hekim veya sağlık kurumu seçme hakkı, yakınları ile ve savunucularıyla temas kurma hakkı gibi hakları ile ilgili ayrıca düzenlemeler yapılmalıdır.

Topluma ya da kendine zarar verme olasılığı bulunan kişilerin özgürlüğünün sınırlanması ve tedaviye zorlanması tıp etiği ve tıp hukuku açısından kabul görmektedir. Türkiye'de de konu ile ilgili düzenlemeler bulunmaktadır. Ancak bu düzenlemeler genel ifadeler taşıyan hükümler içermektedir. Bu durum kişinin özgürlüğünün sınırlanması ve beden bütünlüğüne zorla müdahale edilmesi gibi önemli hakların sınırlanması ile sonuçlanabilen bu uygulamalarda belirsizliklerin olmasına neden olmaktadır. Bu belirsizliklerin uygulamada keyfiliğe yol açmasının önlenmesi için ayrı bir düzenlemenin bulunması önemlidir. Bu düzenlemelerin hazırlanmasında uygulamanın kişi hak ve özgürlükleri açısından ihlallere neden olabileceği, tıp etiği açısından özerklik ve zarar vermeme ilkeleri çerçevesinde önemli tartışmalar getirdiği her zaman göz önünde bulundurulmalıdır. Bu bağlamda, yasaların mümkün oldukça kişi hak ve özgürlüklerini sınırlamayacak yönde açık ve kapsamlı hüküm içermesi, tıp etiği ilkeleri ile desteklenmesi önemlidir.

\section{Bilgi}

Türkiye Biyoetik Derneği tarafından 9-12 Mayıs tarihleri arasında Mersin’de gerçekleştirilen Türkiye Biyoetik Derneği IX. Ulusal Biyoetik Kongresi'nde sunulmuştur.

\section{Kaynaklar}

1. Oğuz NY. Özgüven DH. Psikiyatri ve Etik Sorunları. Klinik Etik. Nobel Tıp Kitabevleri. İstanbul: 2001.Ed. Erdemir DA. Oğuz NY. Elçioğlu Ö. Doğan H. 354-369: 354

2. Zhang Z. ve ark. Involuntary admission and treatment of patients with mental disorder. Neurosci Bull February. 2015;31(1): 99112.

3. Aydın ER., Şehiraltı M., Çözümlenmemiş Bir Konu: Psikiyatrik Bozukluğu Olan Hastanın Gönülsüz/Zorla Tedavi Edilmesi. Psikiyatri Hemşireliği Dergisi. 2010;1(1):39-42.

4. Oğuz NY., Demir B., Hukuki ve Etik Yönüyle Zorla Hastaneye Yatırma. Psikiyatri. Psikoloji ve Psikofarmakoloji Dergisi. 1993;1:367371.

5. Gültekin B.K. ve ark. Bir Psikiyatri Hastanesinde İstemli Ve İstem Dışı Yatışların Sosyodemografik Ve Klinik Özellikleri. Nöropsikiyatri Arşivi. 2013; 50:216-221.

6. Şen N., Süzer Ö. Psikiyatri Hastalarında Zorunlu Yatış ve Zorla Tedaviye Bir Bakış Açısı. Düzce Üniversitesi Sağlık Bilimleri Enstitüsü Dergisi. 2017(7): 176-181.

7. Dalkılıç EE. Türkiye'de Zihinsel veya Ruhsal Engellilerin “Zorla” Tedavisinin Eleştirisi TBB Dergisi 2015(117):11-34.

8. The Protection Of Persosn With Mental IIllness And The Improvement Of Mental Health Care 17 Aralık 1991 tarihli 46/119 sayılı BM Genel Kurul kararıyla kabul edilmiştir. http://www.un.org/documents/ga/res/46/a46r119.htm Erişim Tarihi:16.02.2019

9. Ruh Sağlığı Yasa Taslağı, http://www.psikiyatri.org.tr/uploadFiles/2811201717434-Ruh-Sagligi-Yasa-Taslagi.pdfı. Erişim Tarihi: 14.03.2019

10. Ruh Hekimliği (Psikiyatri) Meslek Etik Kuralları. http://www.psikiyatri.org.tr/tpd-kutuphanesi/belge/311. Erişim Tarihi: 12.03.2019

11. Hiçdurmaz D, Öz F. Bir Etik Problem: Psikiyatride Illaç Araştırmaları Ve Hemşirelik. Hacettepe Hemşirelik Yüksekokulu Dergisi. 2007; 82-91

12. "Biyoloji ve Tıbbın Uygulanması Bakımından İnsan Hakları ve İnsan Haysiyetinin Korunması Sözleşmesi: İnsan Hakları ve Biyotıp Sözleşmesi" Bu sözleşmenin onaylandığına dair kanun, 5013 Kanun numarası ile 9 Aralık 2003 tarihli ve 25311 sayılı Resmi Gazete'de yayımlanarak aynı tarihte yürürlüğe girmiştir.)

13. Kaboğlu i. Ö. Özgürlükler Hukuku, İmge Kitabevi, 6. Baskı, İstanbul 2002.

14. Anayasa Mahkemesi Kararı 2013/1789 başvuru numaralı, 11.11.2015 karar tarihli.

15. Gençcan ÖU. 4721 sayılı Türk Medeni Kanunu Yorumu - Bilimsel Açıklama Son İçtihatlar (II.Cilt). Yetkin Basımevi. Ankara: 2015.

16. Gençcan ÖU. Vesayet Hukuku. Ankara: 2009:261. 
17. Özdemir AE. 19.12.2008 Tarihli İsviçre Medeni Kanunu Değişikliği İle Karşılaştırmalı Olarak Türk Medeni Kanununda Koruma Amaçlı Özgürlüğün Kısıtlanması Düzenlemesi. Dokuz Eylül Üniversitesi Hukuk Fakültesi Dergisi. 2013; 2(15):171-209.

18. Kocaağa K. Koruma Amacıyla Özgürlüğün Kısıtlanması. Gazi Üniversitesi Hukuk Fakültesi Dergisi. 2006;C.X S.1(2): 33-54.

19. Bakanlar Kurulu Kararının tarihi 21/7/2003 No:2003/5690 RG 10.8.2002 No: 25195

20. Yargitay 8.HD.2017/1089 E., 2017/2818 K. 2.3.2017 T.

21. Balcıoğlu İ., Başer S. Z. Hekimlerin karşılaştığı adli ve psikiyatrik problemler, İ.Ü. Cerrahpaşa Tıp Fakültesi, Sürekli Tıp Eğitimi Etkinlikleri, Türkiye'de Sık Karşılaşılan Psikiyatrik Hastalıklar Sempozyum Dizisi No:62 Mart 2008, sayfa 45

22. Yargıtay 18.HD. 2016/9524 E., 2016/9547 K.14.06.2016.

23. Yargitay 18.HD.2016/6467 E. 2016/9883 K.20.06.2016 T.

24. Yargıtay 18.HD.2013/9282 E.; 2013/12347 K. 26.09.2013 T.

25. İmamoğlu H. Hukuki Açıdan, Özellikle Koruma Amacıyla Özgürlüğün Kısıtlanmasına İlişkin Hükümler Çerçevesinde Zorla Tedavi. Erciyes Üniversitesi Hukuk Fakültesi Dergisi. Erzurum: 2012; 3-4:29-60.

26. Yargitay HGK, 2009/13-393 E., 2009/452 K., 21.10.2009 T.

27.Yargitay 2.HD. 2003/1622 E., 2003/2977 K., 6.3.2003 T.

28. Yargitay 2.HD.2011/5506 E., 2012/1336 K. 26.01.2012 T.

29. Yargitay 2.HD. 2002/2323 E. 2002/3027 K. 7.3.2002 T. 